\title{
PHARMACOGNOSTICAL \& PRILIMINARY PHYTOCHEMICAL STUDY OF HIPTAGE BENGHALENSIS (L) KURZ
}

\author{
J. JANORIOUS WINKA*, V.MAITHILI, J.JAYAPRAKASH \\ NARAYANAN, M. RAJKUMAR \& K.L. SENTHIL KUMAR \\ Departments of Pharmacognosy, Padmavathi College of Pharmacy \& Research Institute, Periyanahalli, \\ Dharmapuri - 635205, Tamil Nadu, India.
}

\begin{abstract}
Aim; To study the pharmacognostical and preliminary phytochemical features of stem of Hiptage benghalensis $(L)$ kurz.
\section{Introduction}

In recent years there has been a tremendous increase in demand for herbal drugs due to its safety, efficacy and better therapeutic results. Due to its economic pricing as compared to synthetic or allopathic drugs, which have several therapeutic complications, herbal drugs are more preferred nowadays. Developing of drug as antidiabetic agent involves screening of large number of phytochemical and natural products for their specific and non-specific antidiabetic activity against many types of chemical agents. There are many natural products which are used as potential anti diabetic agents. Looking at the scope of herbal drug and increasing demand of my plant especially in diabetic, hepatoprotective, AIDS, skin diseases, stomatitis and cancer etc. In this Hiptage benghalensis plant is chosen to study the pharmacognostical features.
\end{abstract}

Scientific Name

Synonym

Common Name

\section{Taxonomy}

Kingdom

Subkingdom

Division

Class

Subclass

Order

Family

Genus

Species

\section{: Hiptage benghalensis (L) Kurz}

: Hiptage madoblata

: Hiptage

: Plantae

: Trachiobionta

: Magnoliophyta

: Magnoliopsida

: Rosidae

: Polygalales

: Malpighiaceae (Barbados cherry family)

: Hiptage

: Hiptage benghalensis 


\section{Vernacular names}

Common name

Hindi

Tamil

Manipuri

Kannada

Bengali

Botanical name
: Hiptage, Helicopter Flower

: Madhavi lata

: Vasantakaala malligai

: Madhabi

: Madhvi

: Madhabilata

: Hiptage benghalensis

Description; "Vine-like shrub or liana with scandent branches to $5 \mathrm{~m}$ high (16.5 ft) or more. Leaves simple, opposite, blade usually elliptic and 6-18 cm long (2.5-7 in) with an attenuate tip. Flowers intermittently during the year, flowers many, fragrant, borne in compact axillary racemes. Corolla of five free, elliptic to round, reflexed petals 1-1.7 cm long, white with one petal yellow in the center, margins fringed. Fruit a samara with three spreading, papery oblanceolate to elliptic wing 2-5 $\mathrm{cm}$ long" (Whistler, 2000). White and fragrant flowers of 2-3 cm diameter are borne in erect, pubescent racemes of $10-20 \mathrm{~cm}$ length, the pedicels being $15-20 \mathrm{~mm}$ long. Flowers have a yellow centre and orbicular to elliptic petals that are hairy outside.

Treatment of plants; The stems were washed properly with water to remove the mud or dust if any. Initially it was dried in sunlight for an hour and shade dried completely. Also all the foreign matters like dead or destructed part were removed precautionaly. For this study purpose the stems of Hiptage benghalensis were segregated,dried and then powdered by means of grinder. Then the stems were sieved through sieve no. 60 to get the coarse powder. Then it was used for further studies.

Macroscopical parameters; A large, woody, straggling or climbing shrub with young branches being grey tomentose. The opposite and entire leaves are oblong to ovate-lanceolate, $9-21 \mathrm{~cm}$ long and $4-9 \mathrm{~cm}$ wide, acute or acuminate, glabrous, and have petioles of $1 \mathrm{~cm}$ length. 
Fig. No. 1: A close view of stem of Hiptage benghalensis (l) kurz
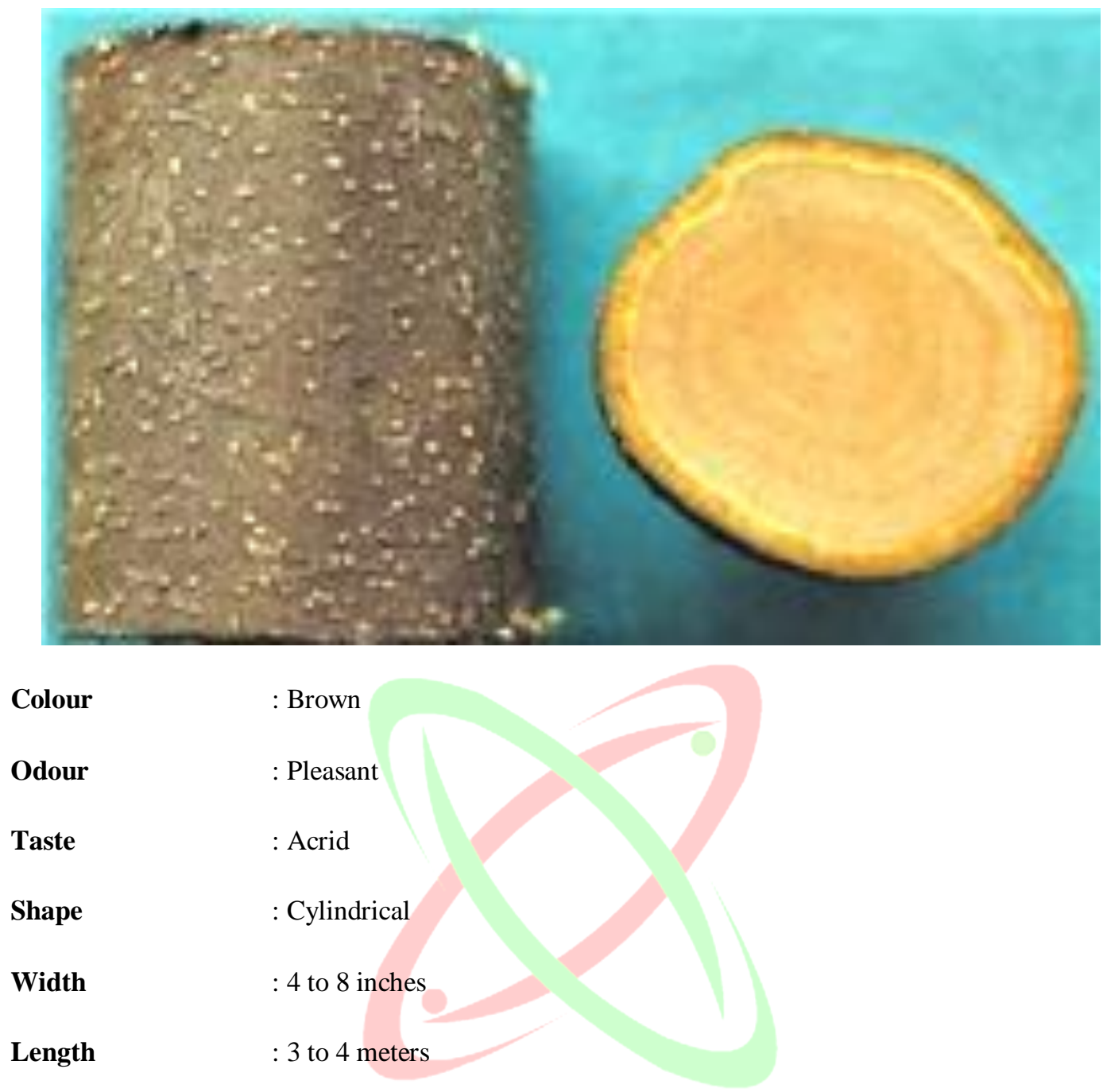

\section{Microscopic analysis:}

Care was taken to select healthy stem of Hiptage benghalensis (L) Kurz. And it was cut, removed and fixed in FAA (formalin, $5 \mathrm{ml}+$ acetic acid $-5 \mathrm{ml}+70 \%$ ethyl alcohol $-90 \mathrm{ml}$ ). After 24 hours of fixing, the specimen was dehydrated with graded series of tertiary-butyl alcohol (TBA) as per the schedule given by Sass (1940). An infiltration of the specimen was carried by gradual addition of paraffin wax (melting point $58-60^{\circ} \mathrm{C}$ ) until TBA solution attained super saturation. The specimen was cast into paraffin blocks. The paraffin embedded specimens were sectioned with the help of Rotary Microtome. The thickness of the section was 10-12 $\mu \mathrm{m}$, dewaxing of the sections was done by customary procedure. The sections were stained with Toluidine blue as per the method published by Since Toluidine blue is a polychromatic stain, the staining results were remarkably good and some cytochemical reactions were also obtained. The dye rendered pink color to the cellulose walls, blue to the lignified cells, dark green to suberin, violet to the mucilage, blue to the protein bodies etc., wherever necessary sections were also stained with safranin, fast-green and iodine potassium iodide.

Microscopical features; The stem is circular in cross-sectional outline with smooth and even surface. It consists of a thin, continuous epidermal layer of small, thin walled squarish cells. Inner to the epidermis are three or four layers of angular collenchyma cells followed by a wide zone of parenchymatous cortex; the cortical cells are four or five layered, thin walled, angular and compact. The stele is eustelic type comprising a hollow cylinder, about 12 discrete vascular bundles separated from each other by wide medullary rays. The vascular bundles are ovate in outline, collateral and open. It consists of an outer small dump of phloem and inner cluster of wide, angular, thick walled xylem elements. 
Fig. No. 2: T.S of stem - entire view

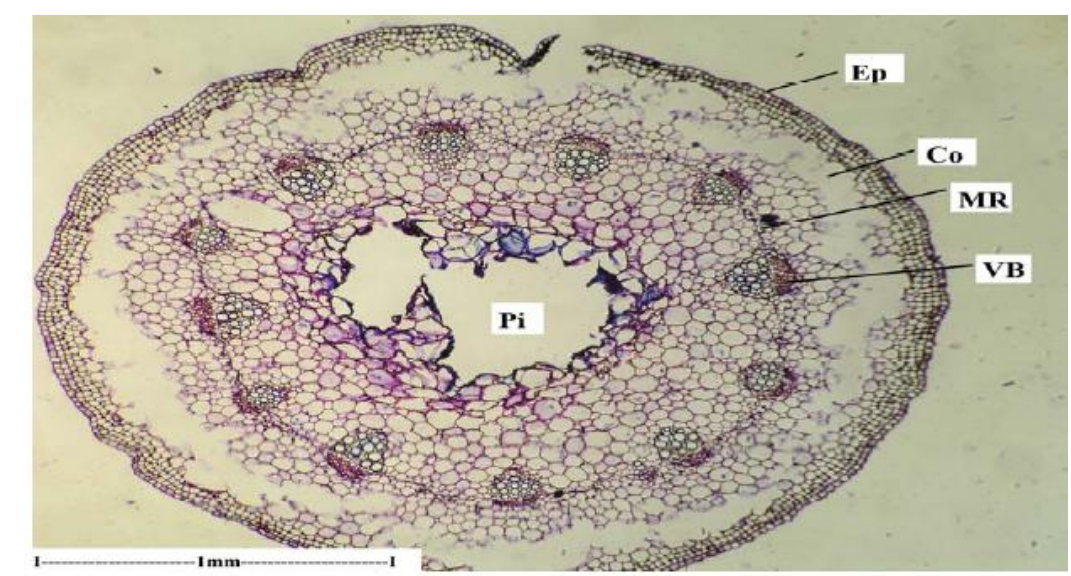

(Ep: Epidermis, Co: Cortex, MR: Medullary ray, VB: Vascular bundle: Pi. Pith)

The pith is wide and the central core is disintegrated forming lysigenous canal the outer pith is intact and consists of large, angular, thin walled compact parenchyma cells.

Fig. No. 3: T.S. of stem: a sector enlarged

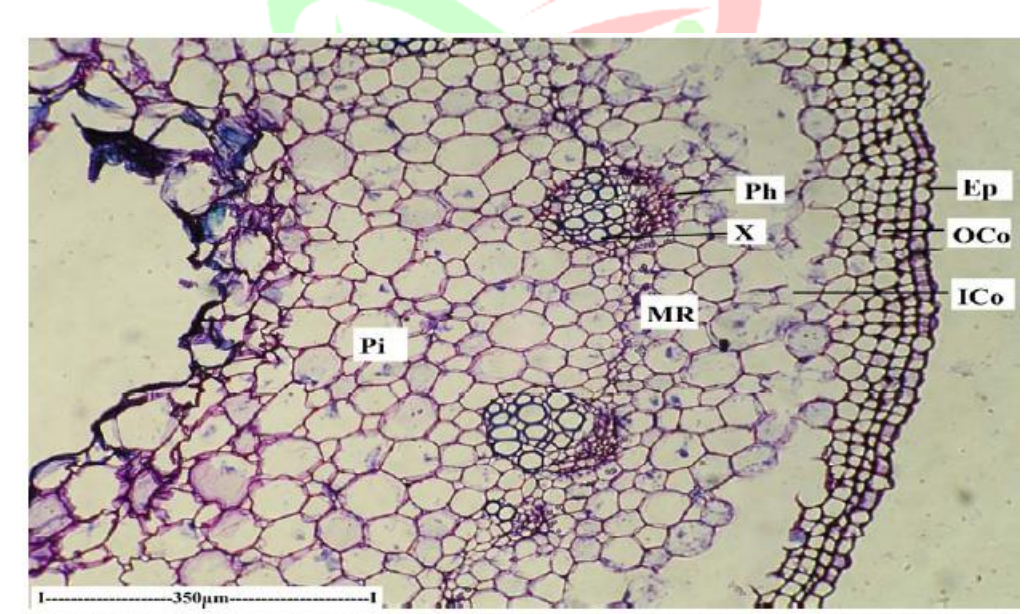

(Ep: Epidermis, OCo: OuterCortex, ICo: InnerCortex, Ph: Phloem,

X: Xylem, MR: Medullary ray, Pi: Pith)

Vascular cylinder; The vascular cylinder is thin, continuous and hollow encircling wide pith. It consists of thin and thick portion of phloem and secondary xylem. The thick portion has a small portion of sclerenchyma abutting the phloem; the phloem has thick arc of sieve-elements and parenchyma cells. Xylem includes dense, scattered wide and thick walled vessels and fibers. 
Fig. No. 4: T.S of old stem: one vascular segment enlarged

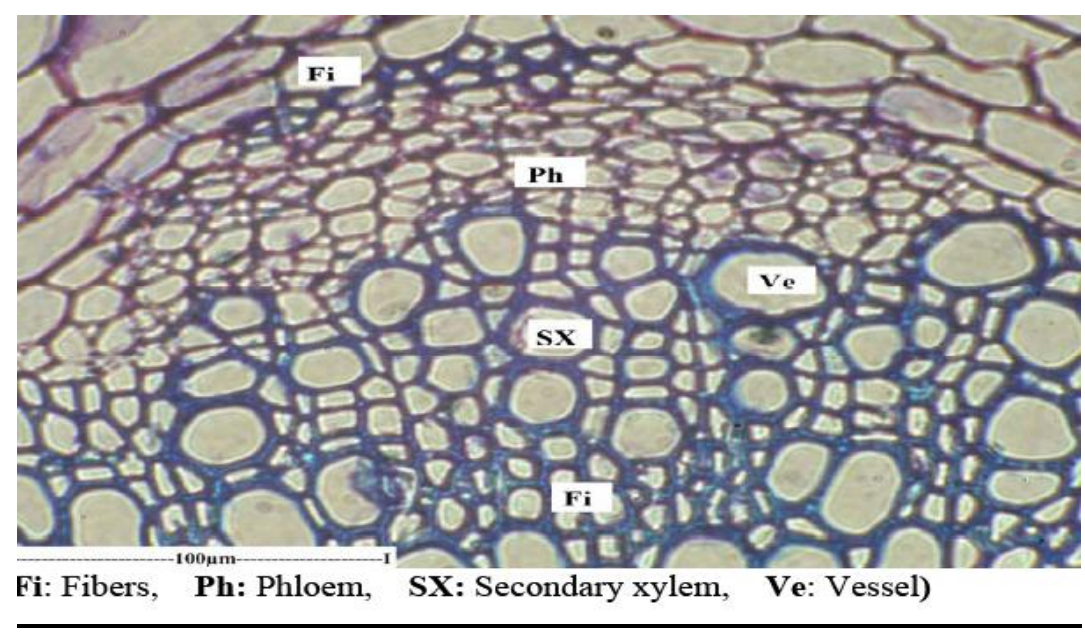

The thin portion of the vascular cylinder has very few vessels or no vessels at all; only xylem fibers were present. The pith is wide, homogenous and includes compact, thin walled parenchymatous cells some of the pith cells are circular, slightly thick walled and were surrounded by rosette of elongated cells.

Powder microscopy; The powder and macerated preparations of the specimen exhibit the following inclusions; vessel elements, fibers and parenchyma cells.

Vessel elements; The vessel elements are common in the powder specimen. They are narrow, long and cylindrical. The length of the element varies from 400-600 $\mu \mathrm{m}$. The short vessel elements have scalariform lateral walls with thick wings; the longer elements have circular multiseriate pits. The end wall perforation was wide and horizontal in the shorter vessel elements, while the perforation was narrow and oblique with longer vessel elements.

Fig. No. 5: Powder microscopy showing vessel elements

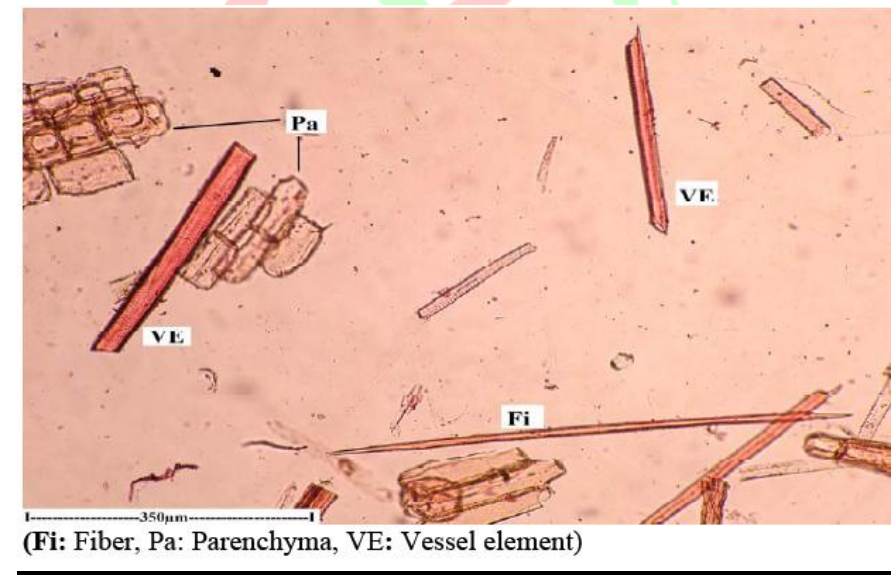

Fibers; The fibers are more abundant than other elements. They are of two types:

a) Some fibers were wider and shorter; the lumen is wide and they are about $420 \mu \mathrm{m}$ long.

b) Some others were narrow with reduced lumen, measuring 400-500 $\mu \mathrm{m}$ long. Pits were not evident on the walls. 
Fig. No. 6: Powder microscopy showing fibers

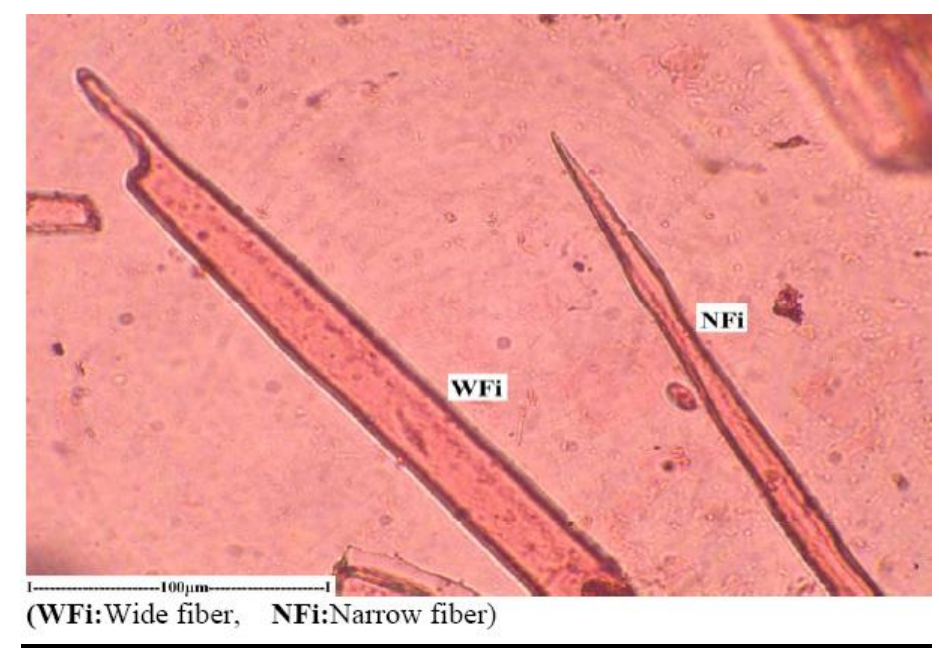

Parenchyma cells; The parenchyma cells of different shape and sizes are common in the powder. Some of them were narrow and much elongated, while some of them were wider and rectangular. The linear oblong cells were $140-280 \mu \mathrm{m}$ long and $30 \mu \mathrm{m}$ wide; the wider cells are $80-120 \mu \mathrm{m}$ wide.

Fig. No. 7: Powder microscopy showing parenchyma cells

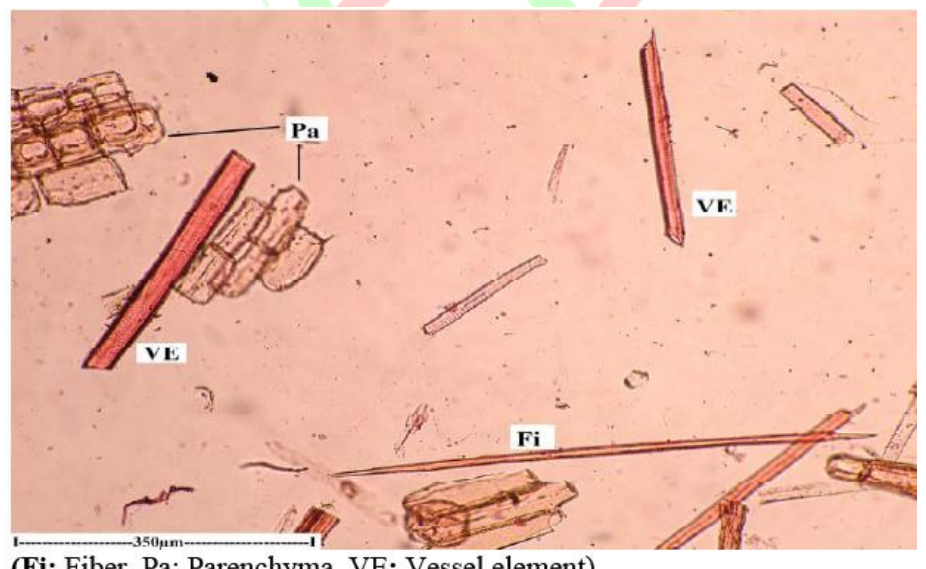

(Fi: Fiber, Pa: Parenchyma, VE: Vessel element)

PHYSICO-CHEMICAL PARAMETERS; Procedure given in Indian Pharmacopoeia was used to determine the different ash values such as total ash, acid insoluble ash, water-soluble ash and sulphated ash. 
Table No. 1: Physico-Chemical Parameters of Powdered Stems

\begin{tabular}{|l|l|l|}
\hline S. No. & Parameters & \% w/w \\
\hline $\mathbf{1}$ & Ash values & \\
\hline & (a) Total ash & 12.8 \\
\hline & (b) Acid insoluble ash & 0.9 \\
\hline & (c) Water soluble ash & 4.1 \\
\hline $\mathbf{2}$ & (d) Sulphated ash & 2.0 \\
\hline & Extractive Values & 24.2 \\
\hline & (a) Alcohol soluble extractive & 13.1 \\
\hline $\mathbf{3}$ & (b) Water soluble extractive & 16.4 \\
\hline
\end{tabular}

Determination of foaming index; Foaming index is mainly performed to determine the saponin content in an aqueous decoction of plant material. Weighed accurately about $1 \mathrm{gm}$ of coarsely powdered drug and transferred to $500 \mathrm{ml}$ conical flask containing $100 \mathrm{ml}$ of boiling water, maintained at moderate boiling at $80-90^{\circ} \mathrm{c}$ for about 30 minutes. Cooled and filtered the decoction into a volumetric flask and added sufficient water through the filter to make up the volume to $100 \mathrm{ml}$ (V1). Cleaned 10 stopper test tubes of uniform dimensions were taken and marked from 1 to 10 . Measured and transferred the decoction into 10 stoppered test tubes in successive portions of $1 \mathrm{ml}, 2 \mathrm{ml}, 3 \mathrm{ml}$ up to $10 \mathrm{ml}$ and made up the final volume of liquid in each test tube with filtered water upto $10 \mathrm{ml}$.Shaken them in a lengthwise motion for 15 seconds uniformly and allowed to stand for 15 minutes and measured the height of foam. Results were assessed as follows; If the height of the foam in every tube is less than $1 \mathrm{~cm}$, the foaming index is less than 100 (not significant). If the height of the foam in every tube is more than $1 \mathrm{~cm}$; the foaming index is more than 1000 . In second case, $10 \mathrm{ml}$ of the first decoction of the plant material is measured and transferred to a $100 \mathrm{ml}$ volumetric flask (V2) and volume is made to $100 \mathrm{ml}$ and followed the same procedure. The readings were tabulated in the Table and the foaming index was calculated by using the formula Foaming index $=1000 /$ a (V1) Foaming index = 1000/a (V2)

Where, $\mathrm{a}=$ volume $(\mathrm{ml})$ of decoction used for preparing the dilution in the tube where exactly $1 \mathrm{~cm}$ or more foam was observed.

Foaming Index $=1000 / 5=200$.

Thus the foaming index for the powdered stem of Hiptage benghalensis (L) Kurz was found to be 200. 
Table No. 2: Foaming index of the powdered stems

\begin{tabular}{|c|l|l|}
\hline S. No. & Test volumetric flask no. $\mathbf{( 1 0} \mathbf{~} \mathbf{)})$ & Height of foam $\mathbf{( c m})$. \\
\hline $\mathbf{1 .}$ & 1 & 0.1 \\
\hline $\mathbf{2 .}$ & 2 & 0.3 \\
\hline $\mathbf{3 .}$ & 3 & 0.9 \\
\hline $\mathbf{4 .}$ & 4 & 1.1 \\
\hline $\mathbf{5 .}$ & 5 & 1.3 \\
\hline $\mathbf{6 .}$ & 6 & 1.3 \\
\hline $\mathbf{7 .}$ & 7 & 1.8 \\
\hline $\mathbf{8 .}$ & 8 & 1.9 \\
\hline $\mathbf{9 .}$ & 9 & 1.9 \\
\hline $\mathbf{1 0 .}$ & 10 & \\
\hline
\end{tabular}

Foaming Index $=1000 / 5=200$.

Thus the foaming index for the powdered stem of Hiptage benghalensis (L) Kurz was found to be 200.

Fluorescence analysis; Many crude drugs show fluorescence when the sample is exposed to ultraviolet radiation. Evaluation of crude drugs based on fluorescence in day light is not of much use as it is likely to be unreliable due to the weakness of the fluorescent effect. Fluorescent lamps are fitted with a suitable filter, which eliminates visible radiation from the lamp and transmits ultraviolet radiation of definite wavelength. Several crude drugs show characteristic fluorescence useful for their evaluation. A very important generalization made by stokes in 1852 stated that in fluorescence, the fluorescent light is always of greater wavelength than the exciting light. Light rich in short wavelength is very active in producing fluorescence so that strong ultraviolet light produces fluorescence in many substance which do not visibly give fluorescence in day light.

The fluorescence studies were done for the powder of the stems of Hiptage benghalensis as such and also by treating the powder with different chemical reagents (Chase and Pratt, 1949). 
Table No. 3: Fluorescence analysis for powdered stems of Hiptage benghalensis

\begin{tabular}{|c|c|c|c|c|}
\hline S. No & $\begin{array}{l}\text { Chemical } \\
\text { Treatment }\end{array}$ & Day Light & $\begin{array}{l}\text { UV Light } \\
(256 \mathrm{~nm})\end{array}$ & $\begin{array}{l}\text { UV Light } \\
(363 \mathrm{~nm})\end{array}$ \\
\hline 1 & Powder as such & Light Green & Green & Light Green \\
\hline 2 & $\begin{array}{l}\text { Powder + } 1 \mathrm{~N} \\
\mathrm{HCl}\end{array}$ & Yellowish & $\begin{array}{l}\text { Yellowish } \\
\text { Green }\end{array}$ & $\begin{array}{l}\text { Yellowish } \\
\text { Green }\end{array}$ \\
\hline 3 & $\begin{array}{l}\text { Powder }+ \\
\text { aqueous } 1 \mathrm{~N} \\
\mathrm{NaOH}\end{array}$ & Green & $\begin{array}{l}\text { Yellowish } \\
\text { Green }\end{array}$ & $\begin{array}{l}\text { Light } \\
\text { yellowish } \\
\text { green }\end{array}$ \\
\hline 4 & $\begin{array}{l}\text { Powder }+ \\
\text { alcoholic } 1 \mathrm{~N}\end{array}$ & Green & Green & Light green \\
\hline 5 & $\begin{array}{l}\text { Powder }+50 \% \\
\text { HNO3 }\end{array}$ & Dark Green & $\begin{array}{l}\text { Fluorescence } \\
\text { Green }\end{array}$ & $\begin{array}{l}\text { Fluorescence } \\
\text { Green }\end{array}$ \\
\hline 6 & $\begin{array}{l}\text { Powder }+50 \% \\
\mathrm{H} 2 \mathrm{SO} 4\end{array}$ & Pale Brown & Greenish & Light Green \\
\hline 7 & $\begin{array}{l}\text { Powder + } \\
\text { Methanol }\end{array}$ & Dark Green & $\begin{array}{l}\text { Yellowish } \\
\text { Green }\end{array}$ & $\begin{array}{l}\text { Yellowish } \\
\text { Green }\end{array}$ \\
\hline 8 & Powder + Water & $\begin{array}{l}\text { Yellowish } \\
\text { Green }\end{array}$ & Greenish & Light Green \\
\hline
\end{tabular}

\section{PHYTOCHEMICAL STUDY}

Extraction; The powdered stem of Hiptage benghalensis (L) Kurz were extracted using ethanol. The \% yield obtained from the extraction process was $23.2 \% \mathrm{w} / \mathrm{w}$.

Qualitative phytochemical analysis results; The ethanolic extract of Hiptage benghalensisi (L) Kurz was found to have the following phytochemicals like flavonoids, triterpenoids, steroids, saponins, tannins, proteins, carbohydrates, phenolic compounds, lignans, gums, glycosides and fixed oils . 
Table No. 4: Qualitative phytochemical analysis of Hiptage benghalensis

\begin{tabular}{|c|c|c|}
\hline S. No & Phytoconstituents & Ethanolic extract \\
\hline 1 & Flavonoids & + \\
\hline 2 & Triterpenoids & + \\
\hline 3 & Steroids & + \\
\hline 4 & Saponins & + \\
\hline 5 & Tannins \& Phenolic compounds & + \\
\hline 6 & Proteins \& Amino acids & + \\
\hline 7 & Carbohydrates & + \\
\hline 8 & Lignans & + \\
\hline 9 & Glycosides & + \\
\hline 10 & Gums & + \\
\hline 11 & Fixed oil & + \\
\hline
\end{tabular}

(+) Present

(-) Absent

CONCLUSION: The stems of the Hiptage benghalensis have been studied to give reports on Pharmacognostical and Preliminary Phytochemical features. These results will help the fellow scientists and others who will research in Hiptage benghalensis $(L)$ kurz to identify the plant and species. 